\title{
Legal Certainty Implementation of Arbitration Decisions in Indonesia
}

\author{
Hendri Jayadi $^{1}$ \\ ${ }^{1}$ Fakultas Hukum, Universitas Kristen Indonesia Jakarta, Indonesia \\ Email : hendrijayadi79@gmail.com
}

\begin{abstract}
The establishment of an arbitration institution as an institution or forum for resolving disputes outside the court is not a result of people's distrust of the current judiciary. In its development, the Arbitration Institution is not only a national issue, but it is seen from its historical development Arbitration institutions become an international issue. On the basis of these international laws, countries that have an interest in arbitration institutions have their own institutions: 1) The International Chamber of Commerce (ICC); 2) The International Center for Settlement of Investment Disputes (ICSID); 3) United Nations Commission on International Trade Law (UNCITRAL / UAR).

Act number 5, 1958 is an agreement on the convention on the Settlement of Disputes between States and Foreigners concerning Investment (convention on settlement of investment disputes between State and National of Other States). This convention is also called the World Bank Convention. Presidential Decree (KEPPRES) No. 34, 1981 which regulates the Ratification of the Convention on Recognition and enforcement of the foreign Abitral Award (New York Convention 1958). At present Indonesia has Act number 30, 1999 concerning Arbitration and Alternative Dispute Resolution becomes the legal basis for alternative dispute resolution outside the Court. The Indonesian National Arbitration Board can be used as a forum for resolving business disputes with written agreements agreed upon by the parties to the dispute under the Act.

Then it becomes another problem, how is the legal force of execution (execution) of the arbitration institution's decision? the implementation of the arbitration award based on articles 59 through article 64 of Law No. 30 of 1999 involves a court institution to carry out a decision (execution), what if there is a third party lawsuit/resistance (derden verzet) to the execution? how can legal certainty be applied in the implementation of the arbitral institution's decision? how is the implementation of foreign arbitration decisions in Indonesia and vice versa, how can Indonesian arbitral awards be implemented in other countries?
\end{abstract}

\section{Keywords: Arbitration, Implementation of national and foreign arbitration awards, Legal certainty}

\section{INTRODUCTION}

Modern developments in international arbitration can be traced to the Jay Agreement (1794) between the United Kingdom and the United States, which formed three arbitration commissions to resolve questions and claims arising from the American Revolution. In the $19^{\text {th }}$ century, many arbitration agreements were concluded where ad hoc arbitration courts were formed to deal with certain cases or to deal with a large number of claims. In contrast to institutional arbitration, ad hoc arbitration is an arbitration that is not administered by a permanent arbitration body but is administered just by the arbitrator or the arbitral tribunal that checks and decides the arbitration dispute concerned [1] Most important was the Alabama claimbitration under the Washington Agreement (1871), in which the United States and Britain agreed to resolve claims arising from the failure of Great Britain to maintain its neutrality during the American Civil War.

International arbitration was given a more permanent basis by the Hague Conference in 1899, which adopted the Hague Convention concerning the peaceful settlement of international disputes, revised by a conference in 1907. The Convention stated: International arbitration has the object of resolving disputes between States by their chosen judges and based on respect for the law. Another way for arbitration implies involvement to submit in good faith to the award.

The Permanent Arbitration Court, consisting of a panel of legal experts appointed by the member governments, from which the litigant governments choose the arbitrator, was founded in The Hague in 1899. Twenty cases were tried between 1902 and 1932, but from that year until 1972 only five cases were handled, mostly 
because of the importance of the Permanent Arbitration Court being reduced by the establishment of the Permanent Justice Court (1922) and its successor, the International Court. Recently, the International Arbitration Tribunal (founded in 1923), which was originally designed to resolve disputes between countries, has offered its services for controversy arbitration between states and individuals or companies. At the beginning of the $21^{\text {st }}$ century, the tribunal has mediated more than 10,000 disputes.

\section{FUNCTION AND SCOPE OF ARBITRATION}

In Article 5 paragraph (1) Law No. 30 of 1999 concerning Arbitration and Alternative Dispute Resolution (hereinafter abbreviated as Law No. 30 of 1999) states that: "Disputes that can be resolved through arbitration are only those in the field of trade and rights which are legally controlled by the parties in dispute." Thus, disputes such as family cases or divorce, whose rights to property are not fully controlled by each party, cannot be resolved through arbitration.

Arbitration is usually used to resolve disputes between members of trade associations and between different exchanges in securities and commodity trading. Contract forms often contain standard arbitration clauses that refer to certain arbitration rules. A number of arrangements between parties in industry and trade also provide arbitration controversies arising from contracts for the sale of manufactured goods, for job service requirements, for construction and engineering projects, for financial operations, for agent and distribution arrangements, and for many other businesses.

The advantage of arbitration is that the speed of controversy can be resolved through arbitration, compared to the long delay in ordinary court procedures. The privacy in the arbitration procedures is also highly valued by the parties in the controversy; unfavorable situation on party credit or deficiencies in manufactured goods disclosed in the arbitration process is unknown to outsiders. However, there are disadvantages in the arbitration process. Because in Anglo-American practice the perpetrators generally do not have to give any reason to accompany an award, it is difficult to develop guidelines for conducting business relations. In addition, this uncertainty makes arbitration awards less predictable. Further barriers to wider use of commercial arbitration are differences in city law and court awards that produce different interpretations of similar arbitration questions and the fact that arbitration awards are usually not published.

\section{INDONESIAN NATIONAL BOARD OF ARBITRATION (BANI)}

BANI is an entity formed by the Indonesian government to enforce law in Indonesia in resolving disputes or disagreements that occur in various trade, industrial and financial sectors, through arbitration and other alternative forms of dispute resolution, including in the corporate sector, insurance, financial institutions, manufacturing, intellectual property rights, licensing, franchising, construction, shipping / maritime affairs, environment, remote sensing, etc. in international laws and customs. This body acts autonomously and independently in law enforcement and justice.[2] Basically there are 3 (three) kinds of award, namely interlocutory award, peace agreement award, and final award. The award on peace agreement can be made if the disputing parties agree to reconcile before the arbitration process begins. This peace award is also final and binding similar to the final award.

Judging from the characteristics of arbitration or ADR, the enforcement of an arbitral award does not require legal formalities. The arbitral award should be carried out voluntarily, where the parties have chosen the arbitration institution as a dispute resolution institution and will follow the established procedures. But as a legal institution, arbitration cannot be separated from legal formalities as stipulated in the law. After the examination of the arbitration dispute has been completed and the award has been given by the arbitrators or the arbitral tribunal, then carrying out the arbitration award must pass the enforcement stage of the arbitration award. Only then an existing dispute can be settled. The enforcement of the arbitration award consists of 2 (two) types, as follows:

\subsection{National arbitration awards}

National arbitral awards can be interpreted as arbitration awards issued by institutional arbitration institutions and/or by individual arbitrators found in the territory of Indonesia and based on the legal provisions of the Republic of Indonesia.

\subsection{International arbitration awards}

Meanwhile, the definition of international arbitration award is found in the provisions of Article 1 point 9 of Law No. 30 of 1999, namely:

"International arbitration award is a award handed down by an arbitral institution or individual arbitrator outside the jurisdiction of the Republic of Indonesia, or the award of an arbitration institution or individual arbitrator which according to the legal provisions of the Republic of Indonesia is considered as an international arbitration award."

Conversely, if the parties in dispute are not Indonesian citizens, but use Indonesian law as the basis for resolving arbitration disputes, then the arbitration award is a national arbitration award instead of an international arbitration award.[3] 


\section{ARBITRATIONAWARDENFORCEMENT}

\subsection{Enforcement of National Arbitration Awards}

Basically, the enforcement of a national arbitration award must be carried out by the parties voluntarily. However, if the national arbitration award is not prepared for the parties to fulfill the enforcement of this national arbitration, then the national arbitration award can be implemented by force.

In order for a national arbitration award to be enforced, the award must be registered first in the registration deed in the Registrar's Office of the District Court. The registration is carried out by submitting and registering the original sheet or the authentic copy of the national arbitration award by the arbitrator or his proxy to the registrar of the District Court. Submission and registration shall be carried out by recording and signing together at the end or at the edge of the award by the registrar of the District Court and the arbitrator or his proxy who submits it. Furthermore, this record shall become and constitute the registration certificate of a national arbitration award.

A national arbitration award that has been listed in the registration deed in the Registrar's Office of the District Court must have been enforced voluntarily no later than 30 (thirty) days after registration. If it has not yet been enforced within that period of time, the national arbitral award can be implemented by force.

The execution order is written on the original sheet and an authentic copy of the arbitration award. The execution is carried out in accordance with the norms in ordinary civil cases that have already had permanent legal force.

A national arbitration award is independent, final and binding, so the Chairperson of the District Court is not permitted to examine the reasons or considerations of the national arbitration award.

\section{ARBITRATIONAWARDENFORCEMENT}

In resolving disputes with international arbitration, the parties have the freedom to choose an arbitration institution from any country to resolve the dispute. In Indonesia, the enforcement of foreign arbitral awards has been practiced since Indonesia ratified the 1958 New York Convention through Presidential Decree No. 34 of 1981. Provisions for the enforcement of international arbitration awards are further stipulated in Article 67-69 of Law No. 30 of 1999 as the renewal of the same provisions as stipulated in the Supreme Court Regulation No. 01 of 1990. International arbitration awards can only be executed if previously they have been registered with the Registrar's Office of the Central Jakarta District, by submitting the necessary documents. Documents to be submitted for the registration shall include the followings:

1) Original or authentic copy of the international arbitration award accompanied by its official translation text in the Indonesian language.
2) Original or authentic copy of the agreement which forms the basis of the arbitration award accompanied by the original translation text in the Indonesian language.

3) A statement from the diplomatic representative of the Republic of Indonesia in the country where the international arbitration award was made, stating that the requesting state is bound by an agreement, both bilaterally and multilaterally with the Republic of Indonesia regarding the recognition and enforcement of international arbitral awards.

An international arbitration award can be made in Indonesia after being registered and obtaining confirmation for execution from the Central Jakarta District Court. In order for an international arbitration award to be recognized and executed in the jurisdiction of Indonesia, there are conditions that must be fulfilled as stated in Article 66 of Law No. 30 of 1999, namely:

1) The award was msfr by the arbitrators or the arbitral tribunal in a country with which Indonesia is bound by an agreement, both bilaterally and multilaterally, regarding the recognition and enforcement of international arbitral awards;

2) Such award is limited by the legal provisions of Indonesia as included in the scope of commercial law;

3) such award may only be enforced in Indonesia to the extent it is not contrary to public order;

4) An international arbitration award may be enforced in Indonesia after obtaining confirmation for execution from the Chairman of the District Court of Central Jakarta; and

5) The referred international arbitration award concerning the Republic of Indonesia as one of the parties in the dispute can only be enforced after obtaining confirmation of registration from the Supreme Court which is subsequently delegated to the Central Jakarta District Court. Regarding the award of the Supreme Court that accepts or refuses to recognize and execute an international arbitration award, no attempt can be made for opposition.

\section{EXAMPLES OF CASES IN INTERNATIONAL ARBITRATION AWARDS}

\subsection{Cases of International Arbitration Awards that Can Be Executed}

International arbitration is always neutral, so it is often the choice of the disputing parties to settle cases fairly. As an illustration, the following are three examples of international arbitration cases with Indonesia's involvement as one of the disputing parties.

- Indonesian Government and Hesham Al Warraq On December 15, 2014, ICSID won Indonesia against a lawsuit by one of Bank 
Century's shareholders, Hesham Al Warraq. This was Indonesia's second victory in a related case, which was previously faced with a former shareholder of the same bank, Rafat Ali Rizvi. In 2011, Hesham, who was Deputy President Commissioner of Bank Century, sued the government for expropriation of shares in the bank.

- Churchill Mining Plc, Planet Mining and the Indonesian Government.

Right on December 6, 2016, the Government of Indonesia succeeded in winning over the lawsuit of two foreign coal mining companies. The award of the international arbitration institution, the International Center for Settlement of Investment Dispute (ICSID) based in Washington DC, rejected the lawsuit of the two companies.

- The Republic of Indonesia Ministry of Defense and Avanti Communications Ltd.

On June 6, 2018, the arbitration court under the London Court of International Arbitration (LCIA) institute decided that Avanti had succeeded in winning a case against the Republic of Indonesia Ministry of Defense. This arbitration process was related to the payment of ARTEMIS Avanti satellite leases by Indonesia.

Finally, in August 2017 Avanti sued Indonesia through the arbitration channel and officially turned off the ARTEMIS in November 2017. For this claim, Indonesia through the Indonesian Ministry of Defense was obliged to pay the loss suffered by Avanti of US\$ 20.075 million by July 31, 2018.

\subsection{Cases of International Arbitration that Cannot Be Executed}

- Pertamina vs Karaha Bodas Company (KBC) Pertamina and Karaha Bodas Company (KBC) entered into a joint operation contract (JOC) dated November 28 , 1994. On Desember 18, 2000, UNICITRAL decided that Pertamina had to pay compensation to KBC. On March 14, 2002, Pertamina filed a lawsuit to abolish the arbitration award with the District Court of Central Jakarta. Judgment of the District Court of Central Jakarta No. 86/Pdt.G/2002PN.Jkt.Pst dated September 9, 2002 annuled the international arbitration award.

- Case of Astro Group vs PT. Ayunda Mitra Prima, PT. First Media, PT. Direct Vision

A dispute arose from the Joint Venture Agreement dated March 11, 2005. On October 6, 2008, Astro Group filed a lawsuit with the Singapore International Arbitration Centre (SIAC). The SIAC Award No. 062 of 2008 won Astro Group. On December 16, 2011, Astro Group registered the SIAC award with the District Court of Central Jakarta. The judgment of the District Court of Central Jakarta stated that the SIAC's award could not be enforced (non exequatur). On Desember 25, 2012, Astro
Group filed a petition for cassation with the Supreme Court. The Supreme Court Judgment No. $877 / \mathrm{K} / \mathrm{Pdt}$. Sus/2012 refused the petition for cassation.

\section{REASONS FOR FAILING ENFORCEMENT OF ARBITRATION AWARDS}

The factors that make an award cannot be enforced are as follows:

- It is contrary to public order;

- The award is deemed to intervene the judicial process in Indonesia;

- A clause of the agreement is in violation of a legitimate cause.

With respect to the arbitration award, the parties may submit a request for cancellation if the award is alleged to contain elements in accordance with Article 70 of the Law No. 30 of 1999 which states:

1). Letters or documents submitted in the examination, after the judgment has been handed down, are admitted to be false or declared false;

2). After the judgment has been handed down, it is found that a conclusive document was hidden by the opposing party; or

3). The judgment is made from the results of deception committed by one of the parties in the examination of the dispute.

\section{ROLE OF THE COURT INARBITRATION}

The Courts have an important role in resolving trade disputes, even though the parties have agreed to resolve the dispute in question through an arbitration institution. The court is asked to intervene when the arbitration process is complete and one of the parties is unwilling to enforce the arbitration award.[4]

In the absence of an international agreement between Indonesia and other countries, there can be no enforcement of foreign awards in the Republic of Indonesia (Article $436 \mathrm{RV})$. Article $436 \mathrm{RV}$ reads as follows:

1). Apart from the conditions stated in article 724 of the Code of Commercial Law and other laws, the decisions of foreign country judges cannot be enforced in the jurisdiction of Indonesia;

2). The cases concerned may be filed to and examined and decided an Indonesian Court;

3 ). In the circumstances excluded in paragraph (1), the decisions of foreign country judges can only be executed after an application has been made to and there is permission from the judge in Indonesia, where the decision must be executed.

4). In case there is such application and permission, the case will not be reexamined. 
The role of the court in supporting the arbitration process is set forth in Article II (3) of the New York Convention that reads as follows:

"The court of a contracting state, when seized of an action in a matter in respect of which the parties have made an agreement within the meaning of this article, shall at the request of one of the parties, refer the parties to arbitration, unless it finds that the said agreement is null and void, inoperative or inpacable of being performed."

The article essentially says that, if a court from a New York Convention participant adjudicates a case that is a matter of an agreement with an arbitration clause made by the parties, it must, at the request of one of the litigants, refer the case to arbitration unless the court finds that the agreement in question is invalid, inoperative or unenforceable.[5]

The role of the court in addition to separability, competence also plays an important role in supporting arbitration through interpretation. This interpretation can be made of the arbitration agreement, the New York Convention, and national law, which covers the public policy and mandatory law, of the relevant court.[6]

\section{NATIONAL ARBITRATION INSTITUTIONS BESIDESBANI}

Because of the high public interest in the arbitration institution, arbitration institutions are formed in accordance with their fields and functions. The arbitration institutions in Indonesia other than BANI include the followings:

\subsection{Badan Arbitrase Syariah Nasional Indonesia (BASYARNAS)}

BASYARNAS is an arbitration institution that handles sharia economic cases, such as banking. This institution was formerly called the Muamallah Indonesia Arbitration Board (BAMUI) which was established in 1993, but changed its name to BASYARNAS in 2003.

\subsection{Lembaga Alternatif Penyelesaian Sengketa Perbankan Indonesia (LAPSPI)}

LAPSPI is a dispute resolution institution that can be an alternative for consumers who have problems with the value of disputes that are not too big. The service of this institution is completely free, so consumers do not need to be bothered with arrangements in court

\subsection{Badan Arbitrase dan Mediasi Penjaminan Indonesia (BAMPI)}

BAMPI is an institution founded by 17 guarantee institutions which are also members of the Indonesian Financial Services Association (APPI). The institution, which was established on April 10, 2015, can help consumer problems related to pawnshops and financing.
The cases to be handled include the circumstances when consumers have complaints about debt collector actions when demanding payments of credit installment.

\subsection{Badan Arbitrase Pasar Modal Indonesia (BAPMI)}

BAPMI is an institution that helps overcome the problem of disputes relating to the capital market. This institution was established in 2002, long before the FSA issued a regulation regarding the existence of LAPS. If you experience problems regarding the capital market, such as about repurchase agreement (repo), consumers can contact BAPMI so they can be helped with mediation.

\subsection{Badan Mediasi Asuransi Indonesia (BMAI)}

BMAI is an institution under the umbrella of the Indonesian Life Insurance Association (AAJI), the Indonesian General Insurance Association (AAUI), and the Indonesian Social Security Insurance Association (AAJSI). The three are members of the Federation of Indonesian Insurance Associations (FAPI).

\subsection{Badan Mediasi Dana Pensiun (BMDP)}

BMDP is a mediating institution that helps with problems related to pension funds. BMDP was established to bridge former employees/employees who have problems/disputes with their pensions. One example of a case that can get assistance from BMDP is the deduction of pension funds due to unclear reasons.

\subsection{Badan Arbitrase Ventura Indonesia (BAVI)}

BAVI is a mediation institution founded in 2014 by four companies: PT Sarana Jatim Ventura, PT Bahana Artha Ventura, PT Pertamina Dana Ventura, and PT Astra Mitra Ventura. This institution focuses on providing mediation assistance related to the issues involving venture capital.

\subsection{Badan Mediasi Pembiayaan dan Pegadaian Indonesia (BMPPI)}

BMPPI is a new mediation institution. This organization was established by organizations in the financing and pawnshop sector together with PT Pegadaian in 2014. The problems that BMPPI solved are the events of damage or loss of the pawned goods. If you as a consumer experience the incident, you can contact the BMPPI to get help in handling the problem.

\section{CONCLUSION}

The development of Arbitration institutions in Indonesia is in line with developments in the international world. Law number 5 of 1958 is an agreement on the convention on 
Settlement of Disputes between States and Foreign Citizens Regarding Investment (convention on the settlement of Investing Disputes Between State and National of Other States). This convention is also called the World Bank convention. Presidential Decree (KEPPRES) No. 34 of 1981 which regulates the Ratification of the Convention on the Recognition and enforcement of foreign Abitral Award (New York Convention 1958). At present Indonesia has Law No. 30 of 1999 concerning Arbitration and Alternative Dispute Resolution becomes the legal basis for alternative dispute resolution outside the court institution. The Indonesian National Arbitration Board can be used as a choice for business dispute resolution forums with a written agreement agreed by the parties to the dispute under the Act.

\section{REFERENCES}

[1] Indonesian Arbitration in the Global World, http://arbitrase.org/arbitrase-ad-hoc/, accessed on June 27,i 2019.

[2] Wikipedia Bahasa Indonesia, Badan Arbitrase Nasional Indonesia, http://id.wikipedia.org/wiki/ Badan_Arbitrase_Nasional_Indonesia, accessed on June 26, 2019.

[3] Rachmadi Usman, Pilihan Penyelesaian Sengketa di Luar Pengadilan, $2^{\text {nd }}$ edition. (Bandung : PT Citra Aditya Bakti, 2013), p. 185.
[4] Wirjono Prodjodikoro, Asas-asas Hukum Perdata Internasional, second edition, (Jakarta : N.V. Van Dorp \& Co, 1954), p. 74.

[5] Mochamad Basarah. Pelaksanaan Asas Ketertiban Umum di Pengadilan Nasional terhadap Putusan Badan Arbitrase Asing (Luar Negeri). Jurnal Wawasan Hukum, Vol. 22 No. 01 February 2010.

[6] Hayadi, M. 2009. Penyelesaian Bisnis Internas Melalui Arbitrase. Ilmu Hukum Journal 4(7).

[7] Indonesian Arbitration in the Global World, http://arbitrase.org/arbitrase-ad-hoc/, accessed on June 27, 2019.

[8] Prodjodikoro, Wirjono. Asas-asas Hukum Perdata Internasional, second edition. Jakarta. N.V. Van Dorp \& Co, 1954), pp. 40 \& 74.

[9] Surianty, Felly. 2014. Pelaksanaan Eksekusi Atas Putusan Badan Arbitrase Nasional Indonesia (BANI) Dan Singapore International Arbitration Centre (SIAC). Universitas Internasional Batam.

[10] Undang - Undang Nomor 30 Tahun 1999 Tentang Arbitrase Dan Alternatif Penyelesaian Sengketa. Citra Aditya Bakti, Jakarta.

[11]Usman, Rachmadi. 2013. Pilihan Penyelesaian Sengketa di Luar Pengadilan, second edition. Bandung. PT. Citra Aditya Bakti, p. 185.

[12]IKAHI. 2009. VARIA PERADILAN. Majalah Hukum Tahun XXIV No. 285 August 2009. 